\title{
POOR FUNCTION OF MICROVASCULAR PROSTHETIC GRAFTS
}

\section{BRAVO ${ }^{1}$, F. TICHÝ ${ }^{2}$, I. MÍŠEK ${ }^{2}$, D. HORKÝ ${ }^{3}$, M. ŚTASTNÁ ${ }^{4}$, J. VÁLKA ${ }^{5}$, E. MANNINO ${ }^{1}$, J. VESELÝ ${ }^{1}$}

${ }^{1}$ Department of Plastic Surgery, Faculty of Medicine, Masaryk University, Brno,

${ }^{2}$ Department of Anatomy, Histology and Embryology, Faculty of Veterinary Medicine,

University of Veterinary and Pharmaceutical Sciences, Brno,

${ }^{3}$ Department of Histology and Embryology, Faculty of Medicine, Masaryk University, Brno,

${ }^{4}$ Institute of Knitting Research, Brno, Czech Republic ${ }^{5}$, Laurea Clinic, Brno, Czech Republic

Laurea Clinic, Brno, Czech Republic

Received November 11, 1997

Accepted March 3, 1998

\begin{abstract}
Bravo, C., F. Tíchý, I. Mísek, D. Horký, M. Śtastná, J. Válka, E. Mannino: Poor Function of Microvascular Prosthetic Grafts. Acta vet. Brno 1998, 67: 43-49.

Four types of knitted microvascular prostheses $(10 \times 2 \mathrm{~mm})$ were implanted into the abdominal aorta in four groups of Wistar rats. The prostheses were made of polyester multifilamentous yarn (groups 1 and 3), or polyester monofilamentous (groups 2 and 4) and finished with polyurethane (groups 1), polylactide (group 2) or a combination of the two polymers (groups 3 and 4). Patency rates one and two months after the implantation for groups $1,2,3$, and 4 were $30 \%, 20 \%, 40 \%$, and $70 \%$, respectively. Collateral blood channels bypasssing the grafts developed in most of rats. No endothelial lining was found in any of the grafts.
\end{abstract}

Microsurgery, vessel, collateral channel, neointima, rat

Patency failures in implanted knitted small-calibre vascular prosthetic grafts made of polyester monofil or yarn were described in our previous paper (Bravo et al. 1997). However, the way to the development of textile grafts as the ideal solution of replacement of microvascular defects (Mehdorn et al. 1979; O'Brien et al. 1984; Hess et al. 1985; Wright et al. 1986) is open thanks to advances in the technology of microvascular prostheses (Jerusalem et al. 1987; Gorbunow and Lebiediew 1988).

The results of our continuing tests of further types of microvascular protheses, motivated by the temporal success of some of the previous experiments (Bravo et al. 1997), are presented in this paper.

\section{Materials and Methods}

Forty male Wistar rats weighing 400-450 g were divided into four equal groups. The animals were anaesthetized by subcutaneous administration of ketamin and xylazine ( $100 \mathrm{mg}$ and $16 \mathrm{mg}$ per $\mathrm{kg}$ live body mass, respectively). After shaving the skin and disinfection with jodisol, the abdominal cavity was opened by a midline incision and the abdominal aorta was carefully exposed and fixed between the left renal artery and aortic bifurcation. Then the lumbar branches were ligated and the aorta was closed with two bulldog clamps. The aorta was severed and the ends were allowed to retract to facilitate the implantation without any tissue resection. The grafts were immersed into Ringer solution containing heparin. A $10 \mathrm{~mm}$ length of the prosthesis with a calibre of $2 \mathrm{~mm}$ was placed as an interposition graft using the following technique: a triangular excision extending over one half of the aortal perimeter was made and the first stitch connecting the apex of the excision and the prosthetic edge was placed. The prosthetic-aortal perimeter of the proximal anastomosis was completed with a running suture using $8 / 0$ Mirafil. After completing the distal anastomosis in the same way, the distal clamp was removed and back flow of blood was checked before removing the proximal one. Some blood usually leaked through the stitch holes, but the bleeding

Address for correspondence:

Doc. MVDr. František Tichý, CSc.

Department of anatomy, histology and embryology

Phone: +420541562200

Palackého 1-3,612 42 Brno. Czech Republic

Fax: $+4205+1562217$

E-mail: anatbrno@iach.cz 
ceased rapidly and the proximal clamp could be removed within several minutes. The mean clamping time was 30 minutes. Careful microvascular technique was used and no antibiotics or anticoagulants were administered. All animals in which technical errors occurred during the surgery were eliminated from the experiment. The rats were observed daily and graft patency was checked one and two months after the implantation by re-laparotomy, visual inspection and the two-forceps technique. A total of 40 implantations were completed.

The prostheses used are given in the following Table 1:

Table 1

\begin{tabular}{|c|c|c|c|c|c|c|c|}
\hline Group & $\begin{array}{c}\mathrm{n} \\
(\mathrm{mm})\end{array}$ & Calibre & $\begin{array}{c}\text { Material } \\
\text { type }\end{array}$ & Filament & $\begin{array}{c}\text { Finish } \\
\text { thickness } \\
(\mu \mathrm{m})\end{array}$ & $\begin{array}{c}\text { Wall } \\
\text { size } \\
(\mu \mathrm{m})\end{array}$ & Pore \\
\hline 1 & 10 & 2 & Polyester & Multi & PU & $100-120$ & $10-15$ \\
\hline 2 & 10 & 2 & Polyester & Mono & PL & $100-120$ & 60 \\
\hline 3 & 10 & 2 & Polyester & Multi & PU + PL & $100-150$ & 35 \\
\hline 4 & 10 & 2 & Polyester & Mono & PU + PL & $100-150$ & 20 \\
\hline
\end{tabular}

Histological examinations of the implants were done in group 1 on day 62 , in group 2 on days $1,2,19$, and 49 , in group 3 on days 1,3 , and 63 , and in group 4 on days $1,8,9,31$, and 69 . The prostheses were removed, flushed with saline, fixed in $2 \%$ phosphate-buffered glutaraldehyde and prepared for light, scanning electron (SEM), and transmission electron microscopy (TEM) according to routine histological methods. All methodological steps of our investigation were approved by the Ethic Commission of the Faculty of Medicine, Masaryk University, Brno. The possessor of a warrant for experiments on laboratory animals is the Clinic of Esthetic and Plastic Surgery (Head - Dr. Veselý).

\section{Results}

\section{Clinical findings}

All the prostheses were patent immediately after the release of the clamps. On day 3 , however, only 50\% in group 1, 40\% in groups 2 and 3 and $70 \%$ in group 4 remained patent. The rats developing acute graft thrombosis died within 3 days after the implantation. After one and two months, the patency rates decreased to $30 \%$ in group 1 and to $20 \%$ in group 2, but remained unchanged in groups 3 and 4 .

\section{Histology}

\section{Group 1}

\section{a) Light microscopy}

The inside surface of the prosthesis was even and smooth without any signs of thrombosis. The inner connective tissue consisted of approx. 20 layers of fusiform cells (fibroblasts) forming here and there a discontinuous lining of the lumen (Plate VII, Fig. 1). The interfilament spaces of the prostheses were filled with cellular connective tissue.

Outside the prosthesis was covered by a sizeable capsule of connective tissue containing leukocyte aggregates, hyalinized areas, organized extravasations, and numerous blood vessels.

\section{b) Scanning electron microscopy}

Sporadic cells or cell groups and clusters of leukocytes (Fig. 2) and here and there artificial fissures were observed on the inside surface of the prostheses. The endothelial lining of the aorta did not exceed to the luminal surface of the prosthesis. 
c) Transmission electron microscopy

The inside surface of the prosthesis was covered by a subtile layer of a rare connective tissue. The fibroblasts of this layer involved cisternae of the granular endoplasmic reticulum and some minute mitochondriae. The sporadic spindle-shaped cells with elongated cytoplasmic spits were distinguishable on the inside surface of the prosthesis too ( Plate VIII, Fig. 3). The intercellular mass was composed by bundles of collagen fibres mostly oriented longitudinally. The spindleshaped cells with areas of slightly granular cytoplasm and signs of smooth muscle cells were sporadicaly visible in deeper levels of the layer of fibrous tissue (Fig. 3).

\section{Group 2}

\section{a) Light microscopy}

On day 1 , the inside surface of the prosthesis was covered by layers of a growing mixed thrombus with solitary fibroblasts. Outside, the prosthesis was covered by a layer of thin loose connective tissue with numerous lymphocytic areas.

Collagen fibrils were apparent in the 20 to $100 \mu \mathrm{m}$ thick lining on day 2 . On day 19 , the lumen of the prosthesis was completely occluded by a thrombus with organized periphery and an erythrocytary mass in the centre. Outside, the prosthesis was covered by a thick layer of loose connective tissue with ample collateral blood channels. Hyalinized areas were seen here and there.

On day 49, the lumen of the prosthesis was patent and the inside surface was covered by twenty layers of fusiform cells (fibroblasts) pervaded by fascicles of collagen and elastic fibrils. Solitary elongated cells with intensively stained cytoplasm were seen on the uppermost layer of the lining (Fig. 4). The outside fibrous capsule contained collateral blood channels of various calibres.

\section{b) Scanning electron microscopy}

The pattern of the inside surface corresponded to the findings of light microscopy on days 1,2 , and 19 . Thrombotic areas consisted of fibrin plaques, erythrocyte and leukocyte clusters and groups of platelets. Slit-shaped collateral blood channels were apparent in the fibrous capsule of the prosthesis and were particularly ample between the capsule and the outside surface of the prosthesis.

The inside surface was smooth with solitary artificial fissures on day 49. The pattern of the inside lining was marked by a fine fibrous structure (Plate IX, Fig. 6). The capsule covering the prosthesis contained ample collateral blood channels (Fig. 5).

\section{c) Transmission electron microscopy}

The appearance and ultrastructure of cells and intercellular mass of the inside surface corresponded fully to the findings in Group 1 (see above).

\section{Group 3}

\section{a) Light microscopy}

The prosthetic lumen was occluded by a typical red thrombus on day 1 . The outside surface was covered by a layer of connective tissue with irregular thickness. On day 3 , the prosthetic lumen was filled by a partly organized thrombus with a considerable part of the fibrin component. The structure of the outer capsule did not change compared with day 1 . The lumen of the prosthesis was completely patent and covered by a $60-100 \mu \mathrm{m}$ thick lining consisting of layers of fibroblasts and bundles of collagen fibres (Plate X, Fig. 7). Areas of light cells (probably chondroblasts) with sporadic central mineralization were seen. No endothelium lining was found. The outer surface of the prosthesis was covered by a coherent, abundantly vascularized capsule of fibrous tissue. No collateral blood circulation was found. 
b) Scanning electron microscopy

On days 1 and 3, the appearance of the prosthesis corresponded to findings in other types of completely occluded vascular grafts. On day 63 , the inside surface of the prosthesis was smooth with only sporadic and small fibrin formations (Fig. 8) and sporadic small orifices (channels, vessels) (Fig. 8). Forced removal of the lining revealed longitudinally oriented fibrillar components of intercellular mass.

c) Transmission electron microscopy

On days 1 and 3 , the ultrastructure of the inside surface of occluded prostheses corresponded to the pattern of a common thrombus. Numerous leukocytes and fascicles of fibrin filaments were found. On day 63 , the inner lining consisted of fusiform flat fibrocytes covered by a basal membrane (Plate XI, Fig. 10). Deeper layers of fibroblasts were arranged longitudinally (Fig. 9). The intercellular matrix contained bundles of collagen fibrils and sporadically elastic filaments (Fig. 9).

\section{Group 4}

a) Light microscopy

On day 1 , the finding was the same as in group 2 . The inside surface was covered by a layer of fibrin and collagen fibrils with solitary fibroblasts on days 8 and 9 . The outer capsule of the prosthesis consisted of abundantly vascularized thin layer of connective tissue. Only minor differences were observed between the findings obtained on days 31 and 69 . The inside surface was covered by a $20 \mu \mathrm{m}$ thick fibrous layer with groups of fusiform cells (fibroblasts) on its surface (Palte XII, Fig. 11). The fibroblasts were more numerous on day 69. The prosthesis was covered by a fibrous capsule with numerous blood vessels and hyalinized areas. Chondrified and mineralized foci were found on day 69. Solitary fascicles of smooth muscle cells and endothelial lining were found in apparently organized walls of ample blood channels.

b) Scanning electron microscopy

On day 1 , the finding was the same as in group 2 . On days 8 and 9 , the prosthesis was occluded by a thrombus with a patent central channel. The patterns on days 31 and 69 were identical with the finding in group 2 on day 49 .

c) Transmission electron microscopy

On days 1,8 , and 9 , the ultrastructure of the inside surface of the prostheses corresponded to findings in other prostheses occluded by thrombi with a common structure. On days 31 and 69, the inside surface was lined by thin layer of connective tissue containing fibroblasts arranged into layers and fascicles of longitudinal collagen fibres. Lining cells containing numerous vacuoles of granular endoplasmic reticulum were seen (Fig. 12). No typical endothelial cells were found.

\section{Discussion}

The need of a prosthetic graft for the repair of microvascular defects is well known. Numerous synthetic materials have been tested during the past 20 years and controversial results of implantation of small-calibre prostheses into the abdominal aorta of rats were published. Thus Christie et al. (1982), using a PTFE prosthesis $(10 \times 1 \mathrm{~mm})$ and Tizian (1981), using the same material $(0,5 \times 1 \mathrm{~mm})$, reported patency rates of $100 \%$ after several 
minutes and $84 \%$ after 1 month, respectively. Clau s et al. (1982), using a PTFE prosthesis $(10 \times 1 \mathrm{~mm})$, found only $50 \%$ patency rate after one month. Hes s et al. (1983), who tested polyurethane prostheses $(10 \times 1.5 \mathrm{~mm})$ and Zelder et al. (1983), using the same material $(75 \times 1.6 \mathrm{~mm})$, reported patency rates of $90 \%$ after 6 months and $53 \%$ after 4 months, respectively.

In our tests of four types of knitted prosthetic grafts, the best patency rate of $70 \%$ after 2 months was obtained in group 4 receiving prostheses made of polyester monofil and finished with polyurethane+polylactide. It should be stressed, however, that this result was partly due to the development of blood channels providing collateral circulation connecting the two anastomoses. The formation of such blood channels was described in our previous paper (Bravo et al. 1997). No blood channels developed in group 3 receiving prostheses made of polyester multifil and finished with polyurethane+polylactide, but the patency rate of $40 \%$ after 2 days - 2 months was to low to warrant clinical testing.

One of the causes of failure of the tested prosthetic grafts was the absence of endothelium. A rapid development of neointima is an important factor in the prevention of thrombosis and also provides an effective barrier against infection (Hess et al. 1983). Another important factor is the biological compliance of the prosthetic material. Better patency rates were reported for the more compliant prostheses by a number of authors (Baird et al. 1977; Hanel et al. 1982; Kidson 1983). The compliance of the prostheses tested in our experiments was apparently poor.

The development of thrombi in vascular grafts depends on the total blood flow rate, blood pressure, surgical technique and thrombogenicity of the prosthetic material (Ganske et al. 1982).

A reconstruction of the inside surface was observed in all the prostheses tested in our experiments. The surface was pervaded by a connective tissue consisting predominantly of several layers of fibroblasts; the uppermost layer of the cells transformed into a "pseudoneointima" of the prosthesis. TEM findings do not allow us to classify them as endothelial cells, but a later differentiation into a true endothelium cannot be precluded. The possibility of such differentiation was suggested by several authors (Mehdorn et al. 1979; Hess 1989; O'Brien et al.; van der Lei et al. 1993; and others). The origin of the cells differentiating into the neo-intima and possibly endothelium is unclear. Our findings of the presence of differentiated cell groups on the inside surface of the prosthesses without any link with the aortic endothelium contradict the concept of Hess et al. $(1983,1985)$ of the endothelium growing from the aorta across the proximal and distal anastomoses and extending to the inner prosthetic surface. It is probable, however, that such growth is limited to narrow segments of the prosthesis adjacent to the anastomoses where repair processes are more intensive. Our observations did not reveal the formation of a typical endothelium in any of the four types of prostheses. Groups of fibrin-covered platelets were found in some segments of the prostheses in groups 2 and 4 . On the one hand, the presence in the prosthetic lumen of blood cells is an evidence of patency, on the other hand the blood cells can activate a part of the fibroblast population to their transformation into endothelium (Brieler et al. 1982). As a matter of fact, a certain degree of differentiation of fibroblasts was evident in our group 3 (see below).

The formation of other components of neo-intima, particularly of smooth muscle tissue, is disputable. O'Brien et al. (1985) and other authors described the growth of smooth muscle cells from the arterial edge towards the prosthesis, and Nomura (1970) reported the transformation of smooth muscle cells into endothelial cells. Apart from the finding of solitary muscle elements in the walls of blood channels (see below), the absence of smooth muscle tissue in prosthetic walls was typical of all the four types of the prostheses tested in our experiments. 
A fibrous capsule developed around the prostheses (groups 1 and 4). The capsule was pervaded by numerous blood vessels and hyalinized (and in some cases probably chondrified - as in group 4) areas were seen. The proliferative activity of the connective tissue surrounding the prostheses was surprising. It is probable that the repair activity of the fibrous tissue is initiated by blood leaking through the pores of the prosthesis wall (Lanzetta and Owen 1993). At the same time a gradual differentiation of the common structural components, including elastic fibres and smooth muscle cells occurred. The origin of the collateral blood circulation is unclear. Possible factors involved in its development include leakage through the a defective suture, reduced flow through the prosthesis due to a partial occlusion, and leakage through large pores of the prosthetic wall. It should be noted in this connection that the inside surface of the blood channels showed a higher degree of organization than the lining of the graft. Apparently the endothelium-like lining of the collateral channels differentiates more rapidly due to the presence of the necessary precursor cells (fibroblasts) (Reichle 1978; Hess 1985).

A different pattern was seen in the prostheses implanted in group 3, in which no collateral blood circulation developed and the inside surface of the grafts was quite smooth consisting of a single discontinuous layer of flat cells covering connective tissue with chondrified areas. Acute occlusion of the prostheses by red thrombi developed in three rats of group 1 on days 1 and 3. The presence of hyalinized or chondrified areas in the prosthetic wall (including the collateral bed) is regarded as an evidence of dystrophic processes. The effects of such areas on the elasticity of the cell wall and in consequence there of its haemodynamic properties are unequivocally adverse (Levy et al. 1986). Therefore, vascular prostheses in which such areas develop within a relatively short time after the implantation cannot be regarded as acceptable.

Although the results of implantation of any of the four types of vascular microprosthetic grafts described here were not fully satisfying, an improvement in comparison with the types tested in our previous experiment (B aird et al. 1977) is evident. Further research of textile microvascular protheses is necessary to improve their patency rates.

\section{Cástečně fungující cévní protézy}

Tkané mikrovaskulární protézy 4 typů byly implantovány $\mathrm{v}$ rozsahu aorta abdominalis čtyřem skupinám potkanů kmene Wistar. Protézy byly vyrobeny jednak z multifilamentózního polyesteru (skupina 1 a 3 ) a jednak z polyesteru monofilamentózního (skupina 2 a 4). Vnitřní povrch protéz byl potažen bud polyuretanem (skupina 1) nebo polylaktidem (skupina 2) nebo kombinací obou polymerů (skupina 3 a 4). Průchodnost protéz jeden a dva měsíce po implantaci byla u krys z 1 . skupiny $30 \%$, z 2 . skupiny $20 \%$, z 3. skupiny $40 \%$ a z 4 . skupiny $70 \%$. Ve většině případů byl vytvořen kolaterální oběh $v$ podobě krevních splavů. Endotelová výstelka nebyla nalezena u žádné protézy.

\section{Acknowledgements}

This work was supported by the Ministry of Health CR (grant IGA MZ ČR 4301-3) and the Ministry of Industry and Trade CR (grant MP-3320/09/96).

\section{References}

BAIRD, N., KIDSON, G., L'ITALIEN, J., ABBOT, M. 1977: Dynamic compliance of arterial grafts. Am. J. Physiol. 233: 568-572

BRAVO, C., TICHÝ. F., MÍŠEK, I., HORKÝ, D., ŠTASTNÁ, VÁLKA, J., VESELý, J. 1997: Patency failures in microvascular prosthetic grafts. Acta vet. Brno 66:183-188 
BRIELER, H. S., THIEDE, A., BECK, Ch. 1982: Monocytogenic endothelialization in dacron grafts. J. Cardiovas. Surg. 23: 483-489

CHRISTIE, B. A., KOTHARANATHAN, V., PERLOFf, I. J. 1982: Minute vascular replacements. Arch. Surg. 117: $1290-1294$

CLAUS, P. L., GLOVICZKI, P., HOLLIER, L. H., KAYE, M. P. 1982: Patency of polytetrafluoroethylene microarterial prostheses improved by ibuprofen. Am. J. Surg. 144: 180-185

GANSKE, J. G., DEMUNTH, R. J., MILLER, S. M., BUCK, D. C., DOLPH, J. L. 1982: Comparison of expanded polytetrafluoroethylene microvascular grafts to autogenous vein grafts. Plast. Reconstr. Surg. 70/2: 123-201

GORBUNOW, G. N., LEBIEDIEW, L. W. 1988: Vascular prosthesis made of polyester threads in microsurgery. Polim. Med. 18: $245-253$

HANEL, K. C., MCCABE, C., ABBOT, W. M., FALLON, J., MEGERMAN, J. 1982: Current PTFE grafts. Ann. Surg. 195: 757-463

HAYHURST, J. J. W., O'BRIEN, B. 1975: An experimental study of microvascular technique, patency rates and related factors. Brit. J. Plast. Surg. 28: 128

HESS, F., JERUSALEM, C., BRAUN, B., GRANDE, P. 1983: Evaluation of the rate of fibrous microvascular polyurethane prostheses after implantation in the rat aorta. Microsurgery 4: 178-181

HESS, F., JERUSALEM, C., BRAUN, B., GRANDE, P. 1985: Three years experience with experimental implantation of fibrous polyurethane microvascular prostheses in the rat aorta. Microsurgery 6: $155-162$

JERUSALEM, C., HESS, F., WEENER, H. 1987: The formation of a neo-intima in textile prostheses implanted in the aorta of rats and dogs. Cell Tissue Res. 248: 505-510

LANZETTA M., OVEN E. R. 1993: Use of the 3m precise microvascular anastomotic system in grafting $1-\mathrm{mm}$ diameter arteries with polytetrafluoroethylene prostheses: a long-term study. J. Reconstr. Microsurg. 93: 173-181

LEIDNER, J., WONG, E. W. C., MACGREGOR, D. C., WILSON, G. J. 1983: A novel process for the manufacturing of porous grafts: process description and product evaluation. J. Biomed. Mater. Res. 17: 229-247

LEVY, R. J., SCHOOR, F. J., SHERMAN, F. S., NICHOLS, J. N., HAWLEY, M. A., LUND, S. A. 1986: Calcification of subcutaneously implanted tampons of collagen types I. Am. J. Pathol. 122: 71-82

KIDSON, I. 1983: The effect of wall mechanical properties on patency of arterial grafts. Ann. R. Coll. Surg. Engl. 65:24-29

MEHDORN, M., TOWNSEND, J. J., WEINSTEIN, P. R., CHATER, N. L., MEYERMANN, R., BUNCKE, H. J. 1979: Endothelialization of a new arterial microvascular graft material. Scan. Electr. Microsc. 3: 851-856

NOMURA, Y. 1970: The ultrastructure of the pseudo-intima lining synthetic arterial grafts in the canine aorta with special reference to the origin of the endothelial cell. J. Cardiovasc. Surg. 11:282-291

O'BRIEN, C. J., VELKOU, D., HARRIS, J. P., MAY, J. 1984: One milimetre polytetrafluoroethylene (gore-tex) as a microvascular prosthesis: technique and early patency. Aust. N. Z. J. Surg. 54: 469-476

O'BRIEN, C. J., WILSON, E. A., VELKOU, W. D., HARRIS, J. P., MAY, J. 1985: Experimental microvascular polytetrafluoroethylene grafts: 6 months patency. Plast. Reconstr. Surg. 765: 748-752

REICHLE, F. A. 1978: Criteria for evaluation of new arterial prosthesis by comparing vein with dacron femoropopliteal bypasses. Surg. Gynecol. Obstet. 146: 714-720

TIZIAN, C. 1981: Patency rates in microvascular prostheses: an experimental study. Br. J. Plast. Surg. 34: 72-75

van der LEI, B., DILK, F., BARTELS, H. L., JONGEBLOED, W. L., ROBINSON, P. H. 1993: Healing of microvenous PTFE prostheses implanted into the rat femoral vein. Brit. J. Plast. Surg. 46: 110-115

WALDEN, R., L'ITALIEN, G. J., MEGERMAN, J., ABBOT, W. M. 1980: Matched elastic properties and successful arterial grafting. Arch. Surg. 115: 1166-1169

WRIGHT, C. B., WHITE, R. A., HIRATZKA, L. F., MORIN, R. P., MITTS, D. L. 1986: Small caliber vascular grafts-alternatives. Vascular Graft Update: Safety and Performace ASTM, STP 898, pp. 60-67

ZELDER, O., WERNER, H. H., JERUSALEM, C. R. 1983: The use of microvascular grafts as an arterial substitute in the abdominal aorta of the rat. Microsurgery 4: 157-163 
Plate VII.

Bravo C. et al.: Poor Function... pp. 41-47

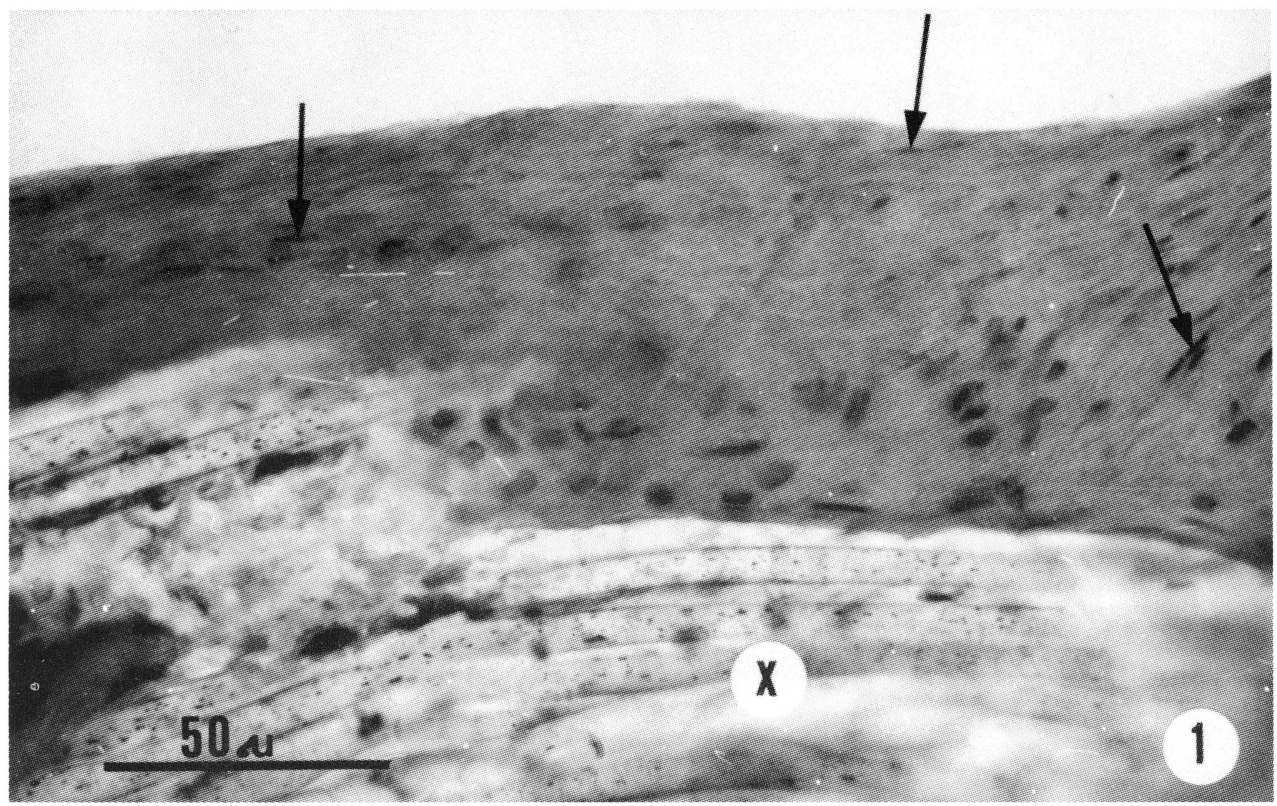

Fig. 1: Inside surface of a prosthesis; fibroblasts $(\rightarrow)$ in a layer of connective tissue; fascicles of prosthetic filaments (x). Group 1, day 62. HE, $\times 600$.

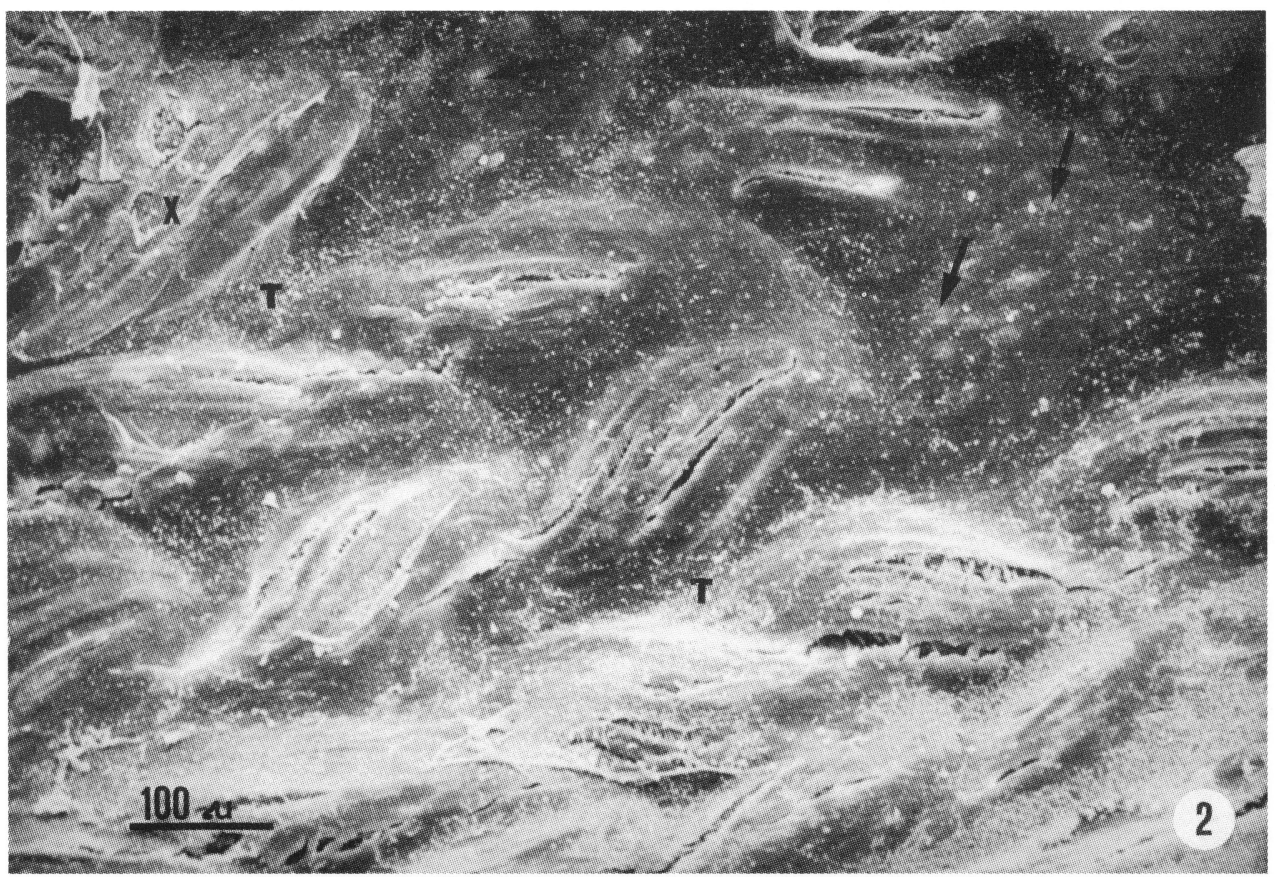

Fig. 2: Inside surface of the prosthesis shown in Fig. 1; prosthetic filaments (x), solitary endothelia cells $(\rightarrow)$; groups of thrombocytes $(\mathrm{T})$. Group 1 , day 62. SEM,$\times 180$. 


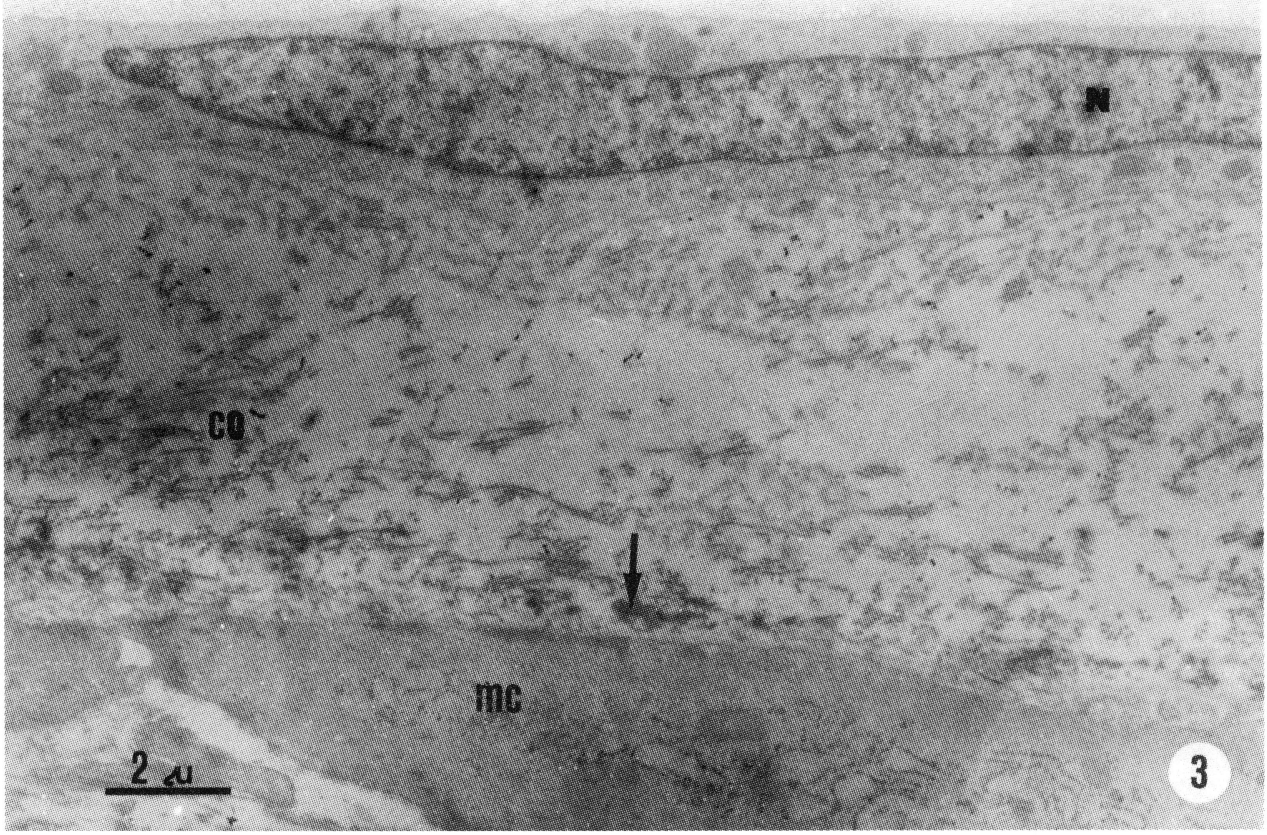

Fig. 3: An elongated cell with nucleus $(\mathrm{N})$ on the inside of prosthesis. Fascicles of collagen fibrils (co); elastic fibres $(\rightarrow)$. A part of the spindle-shaped cell with granular cytoplasm $(\mathrm{mc})$ in the deeper level. Group 1, day 62 . TEM, $\times 8000$.

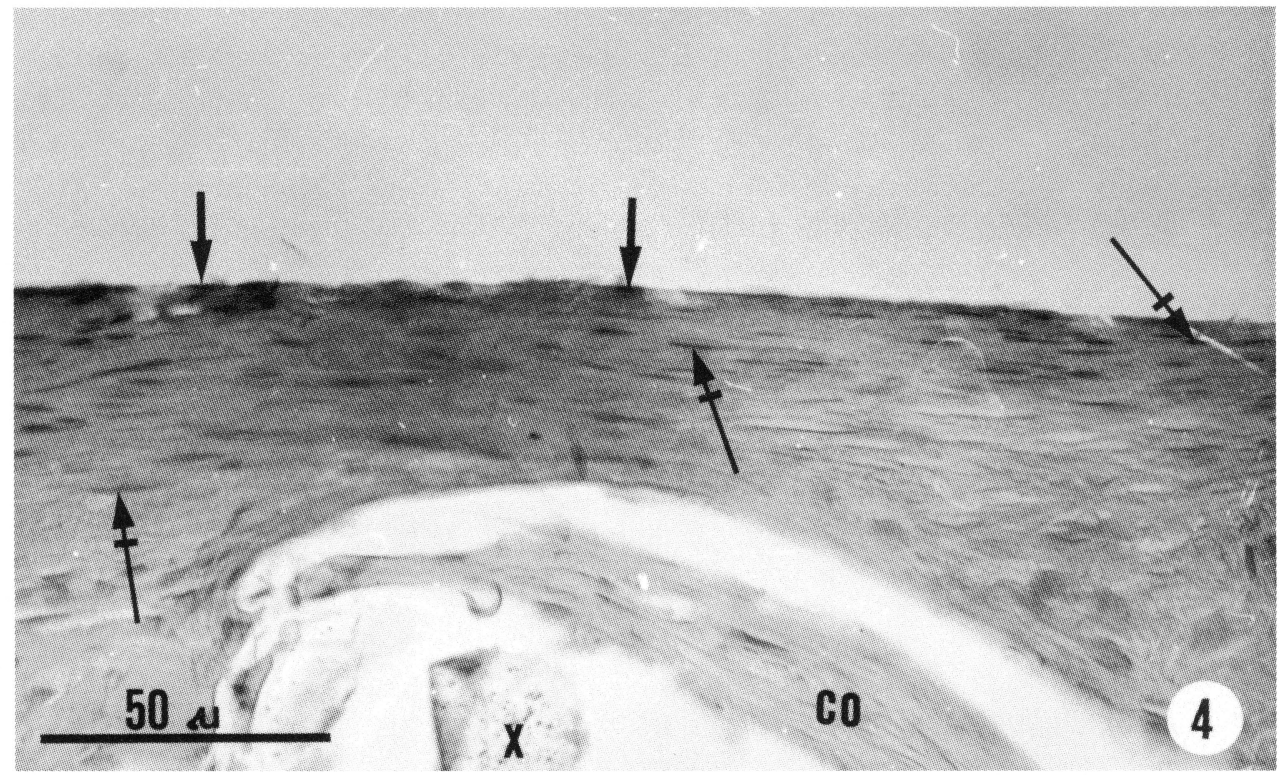

Fig. 4: Inside surface of a prosthesis; fusiform fibroblasts in the fibrous layer $(\rightarrow)$; solitary surface cells $(\rightarrow)$; prosthetic filaments (x); fascicles of collagen fibres (co). Group 2, day 49. HE, $\times 600$. 
Plate IX.

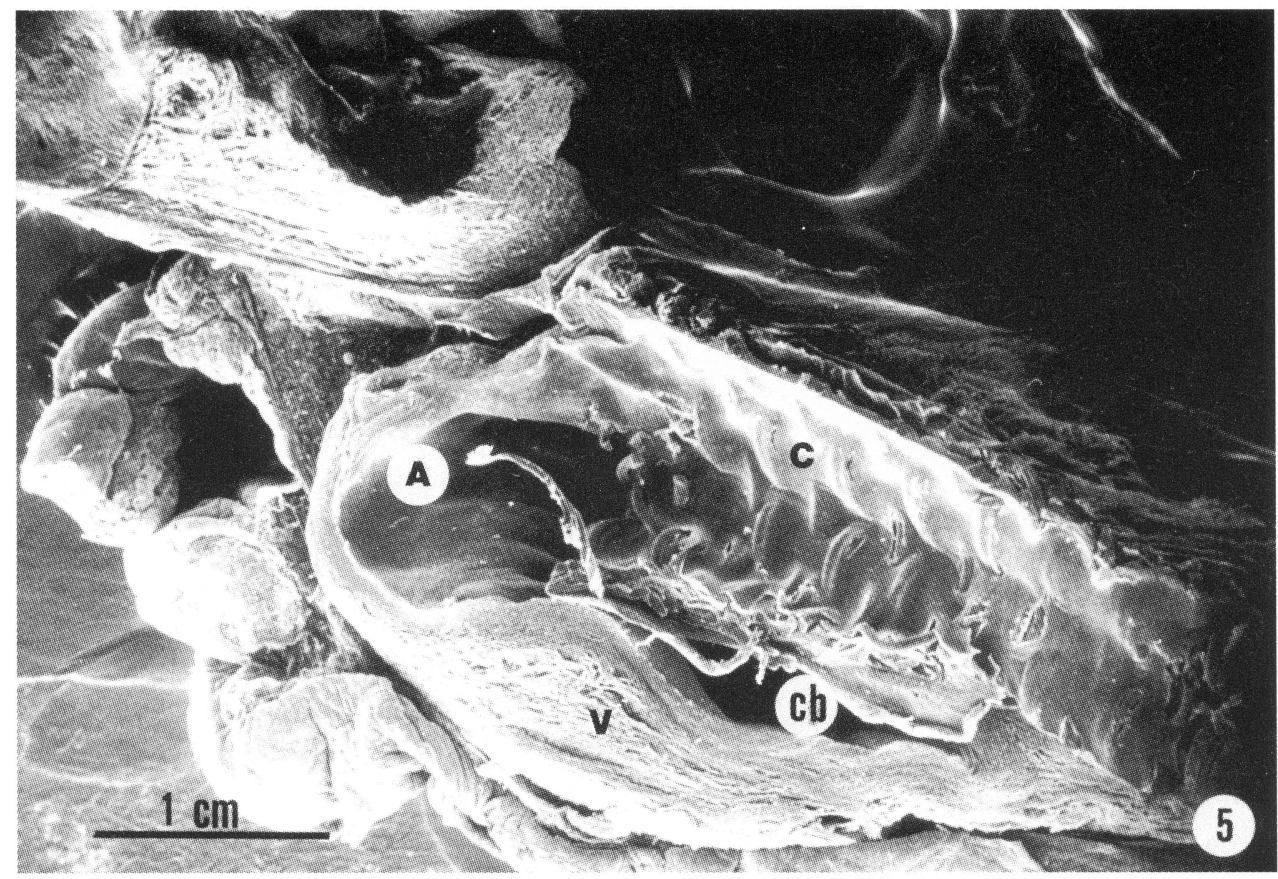

Fig. 5: Inside graft surface (C); sizeable fibrous capsule (V) with an ample collateral blood channel (cb) originating from the aorta (A) before the cranial anastomosis. Group 2, day 49. SEM, $\times 30$.

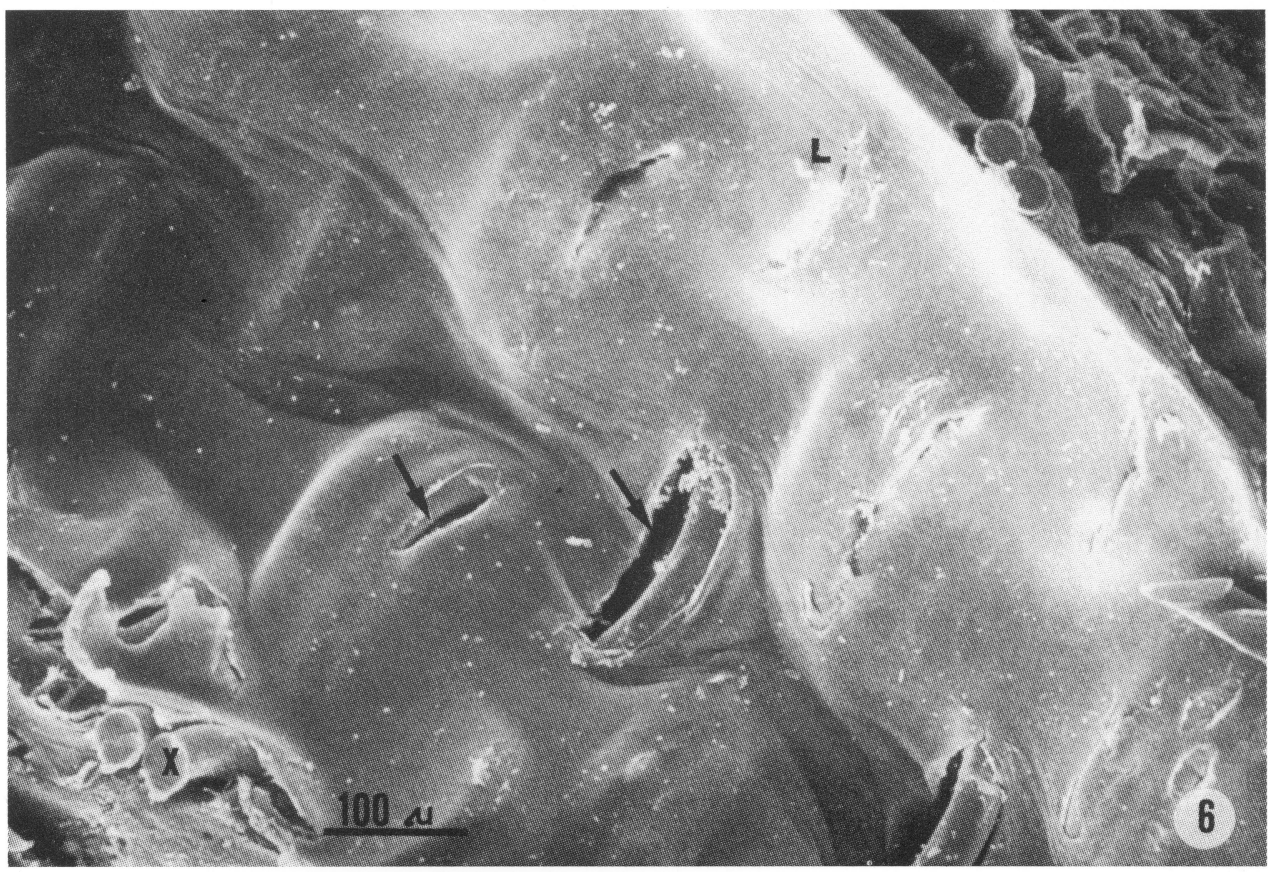

Fig. 6: Inside surface of the prosthesis shown in Fig. 3; artificial fissures $(\rightarrow)$; a group of leukocytes (L); prosthetic filaments (x). Group 2, day 49. SEM, $\times 180$. 
Plate X.

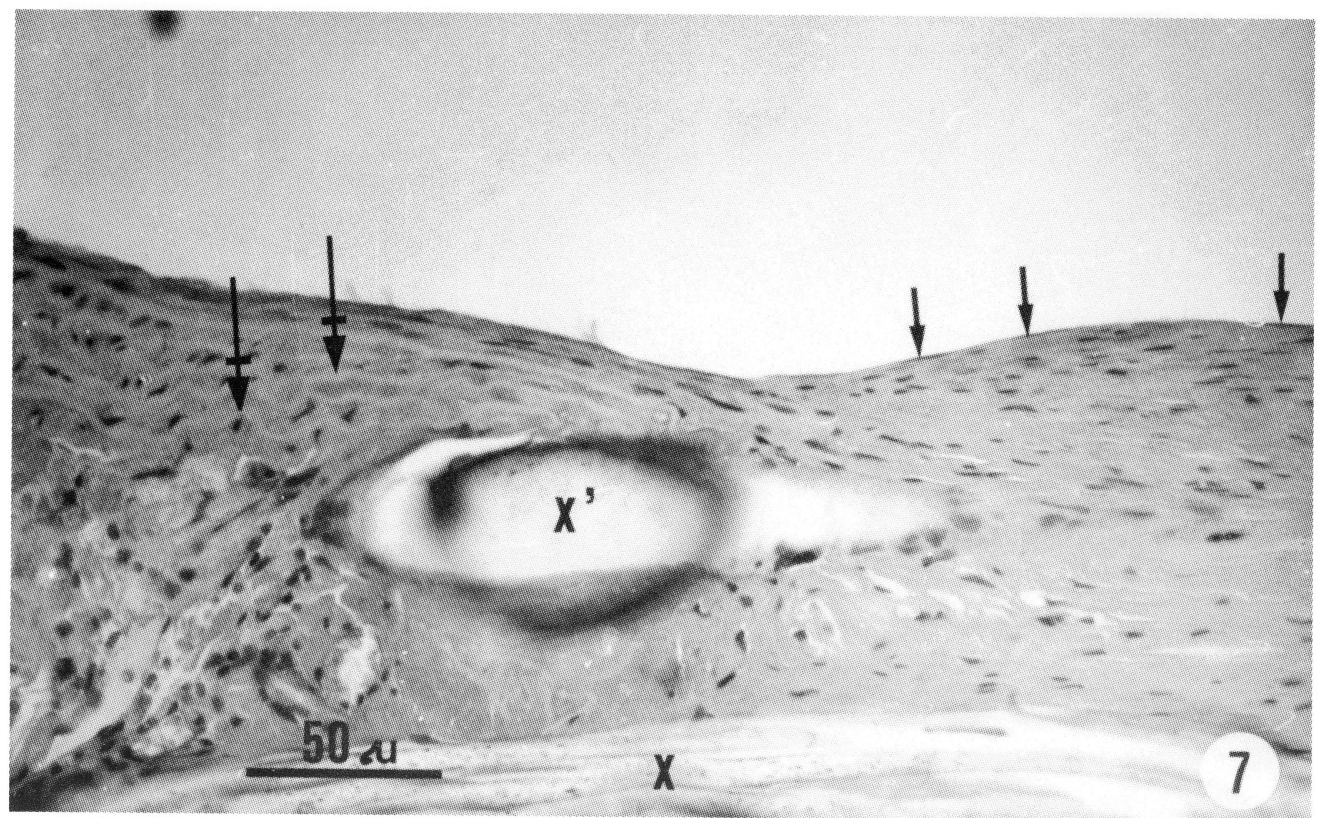

Fig. 7: Cranial anastomosis; suture material (X'), prosthetic filaments (X); elastic membrane of the aortal wall $(\rightarrow)$; fusiform cells $(\rightarrow)$ on the inside graft surface. Group 3, day 63 . HE, $\times 400$.

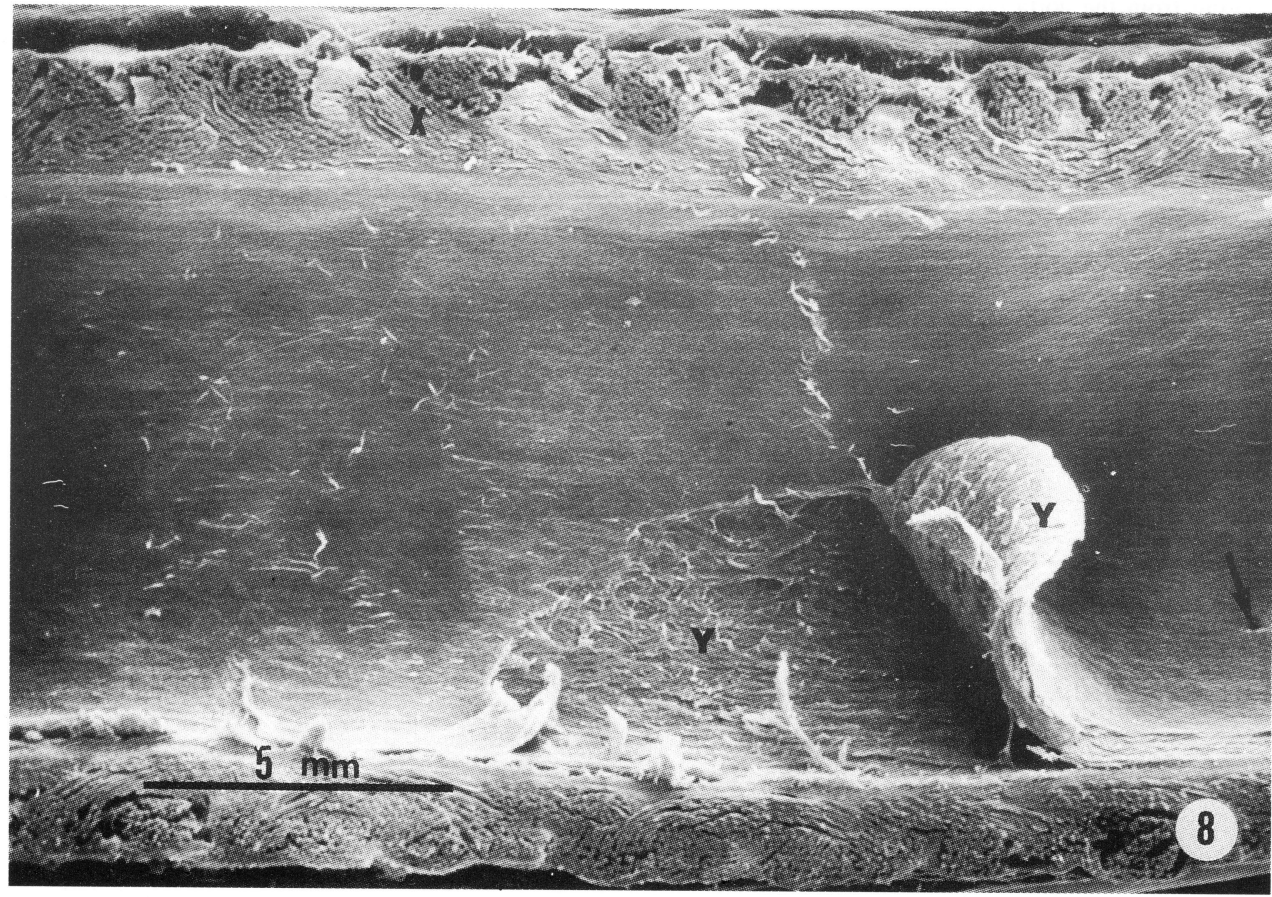

Fig. 8: Graft lumen: prosthetic filaments (x); artificially detached part of the fibrous lining (Y); a small orifice in the inside surface $(\rightarrow)$. Group 3, day 63. SEM, $\times 75$. 
Plate XI.

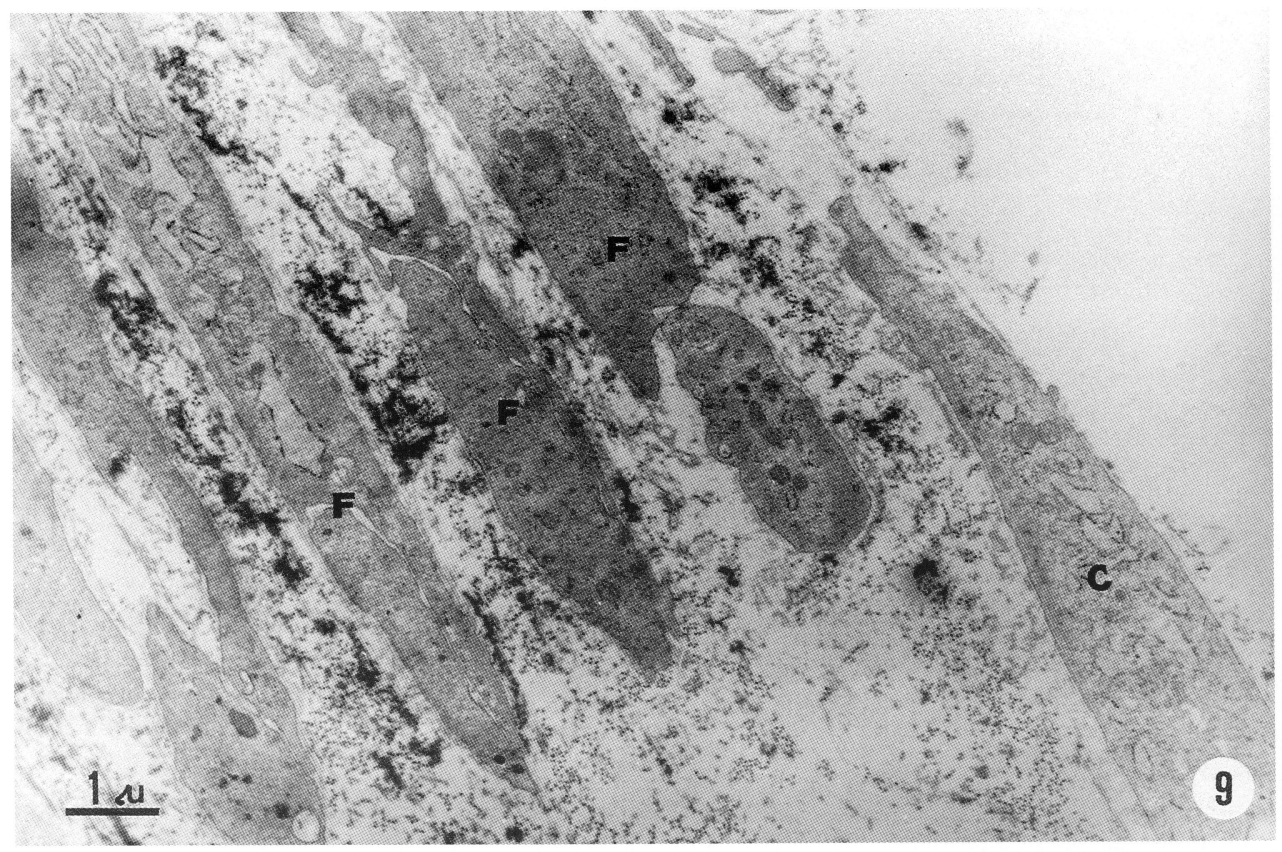

Fig. 9: A fusiform surface cell (C) with numerous cisternae of granular endoplasmic reticulum; fibroblasts (F) arranged into layers with irregularly oriented collagen fibrils between them. Group 3, day 63. TEM, $\times 12000$.

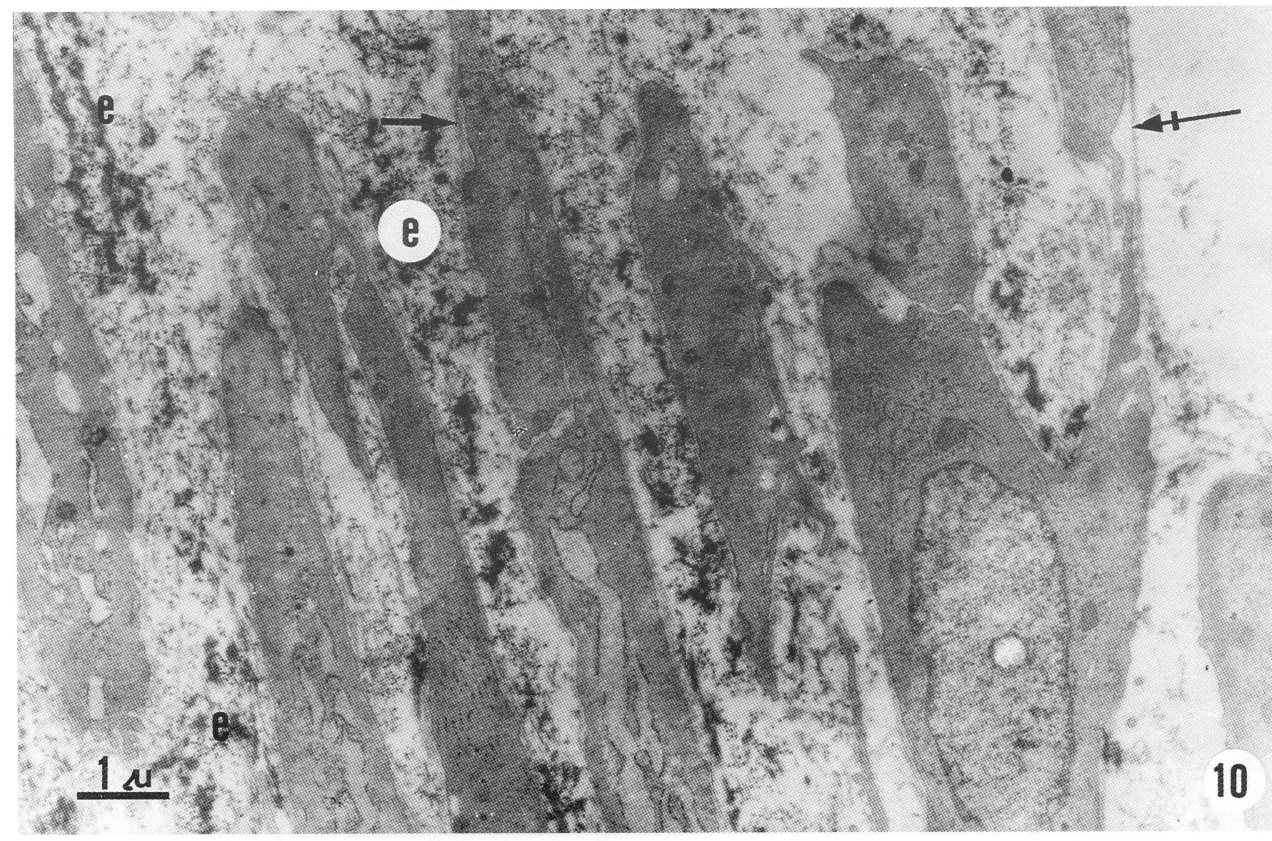

Fig. 10: A remnant of the basal membrane on the inside surface $(\rightarrow)$; basal membrane of the middle layer of fibroblasts $(\rightarrow)$; elastic fibres (e). Group 3, day 63. TEM, $\times 12000$. 
Plate XII.

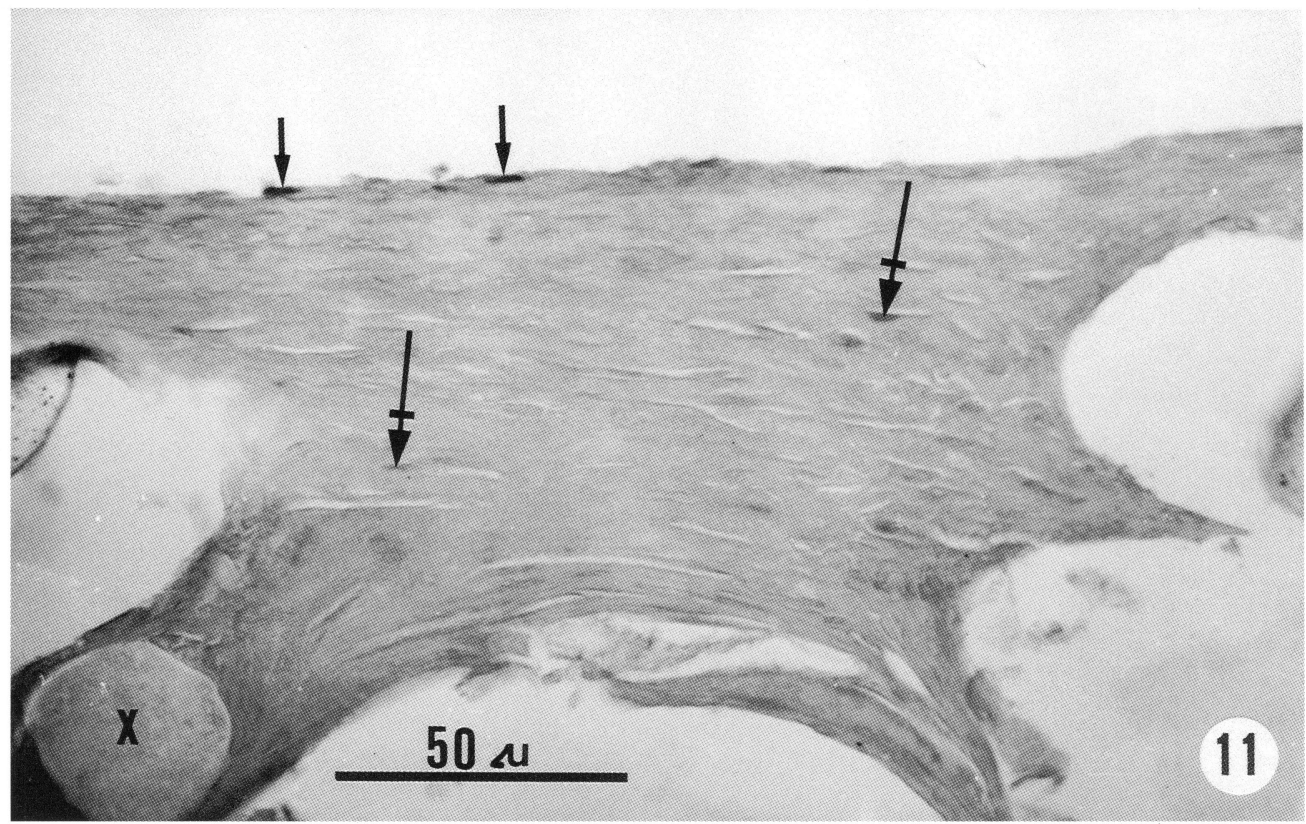

Fig. 11: Inside surface of a prosthesis; fibroblasts $(\rightarrow)$ in the layer of connective tissue; solitary fusiform cells on the surface $(\rightarrow)$; prosthetic filaments $(\mathrm{x})$. Group 4, day 31. HE, $\times 600$.

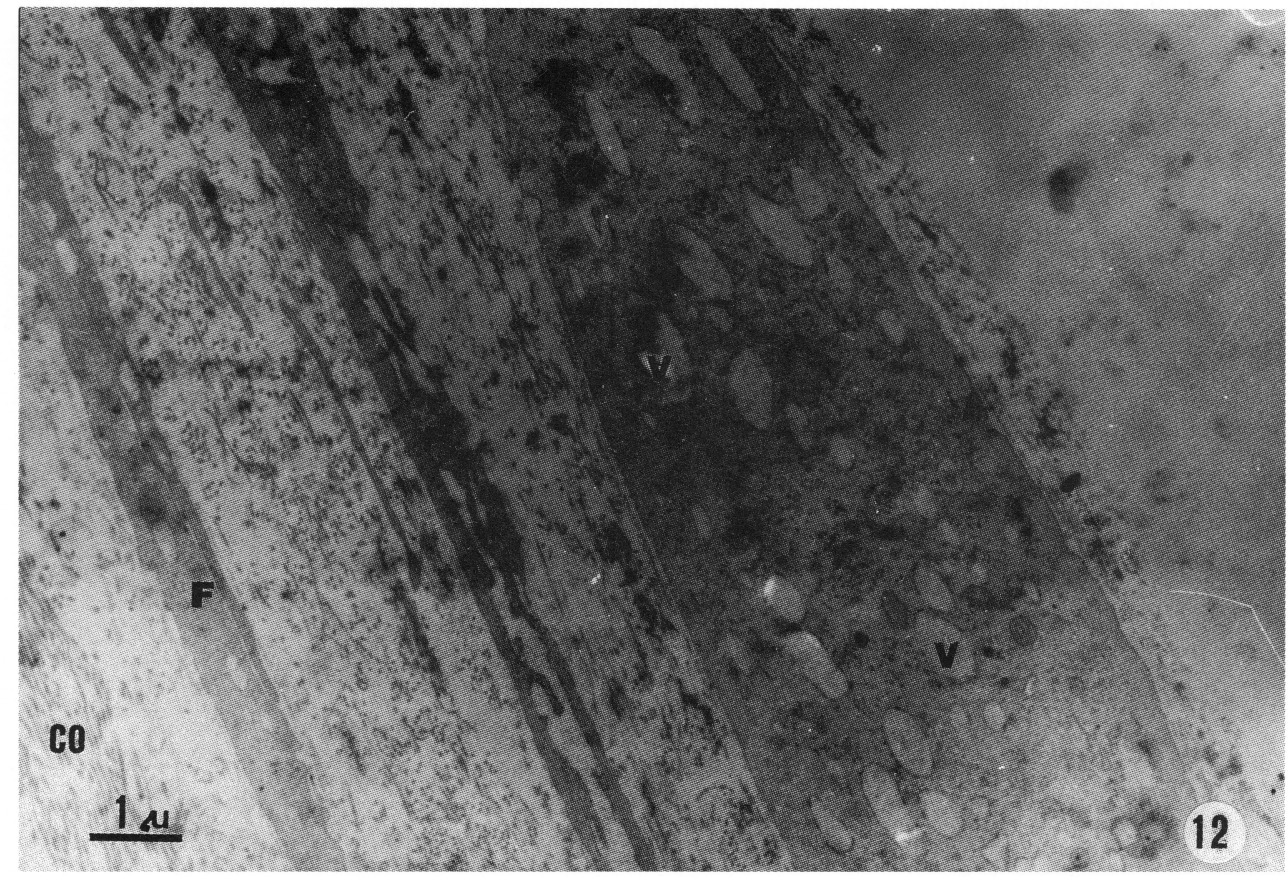

Fig. 12: An elongated cell on the inside surface containing cisternae of granular endoplasmic reticulum (V) in the cytoplasm; projections of fibroblasts (F) and collagen fibrils (co) in deeper layers of the graft wall. Group 4, day 69. TEM, $\times 12000$. 